\title{
Digital Data Set of Generalized Lithogeochemical Characteristics of Near-Surface Bedrock in the New England Coastal Basins
}

This Fact Sheet provides information on a digital data set that contains generalized lithogeochemical characteristics of near-surface bedrock in the New England Coastal Basins study area of the U.S. Geological Survey's National Water Quality Assessment (NAWQA) Program. It can be used in a geographic information system (GIS) to analyze and interpret water-quality and ecosystem conditions. For example, it has been used to characterize water quality in bedrock aquifers, to determine strategies for monitoring ground-water quality, and to characterize watersheds for surface-water and biological studies. The digital data set, the associated metadata, and the related files are available on the World Wide Web at http://water.usgs.gov/pubs/of/ ofr02-007

\section{Introduction}

As part of the U.S. Geological Survey's National Water-Quality Assessment (NAWQA) Program, water quality in the New England Coastal Basins (NECB) study area is being characterized. Surface water, ground water, and aquatic biota are being studied in a 23,000 square-mile area in western and central Maine, eastern Massachusetts, most of Rhode Island, eastern New Hampshire, and a small part of eastern Connecticut (fig. 1). Major drainage basins in the NECB include the Kennebec, Androscoggin, Saco, Merrimack, Charles, and Blackstone Rivers (Flanagan and others, 1999). As part of the study, a digital data set has been created that classifies the bedrock units of the NECB study on the basis of similar

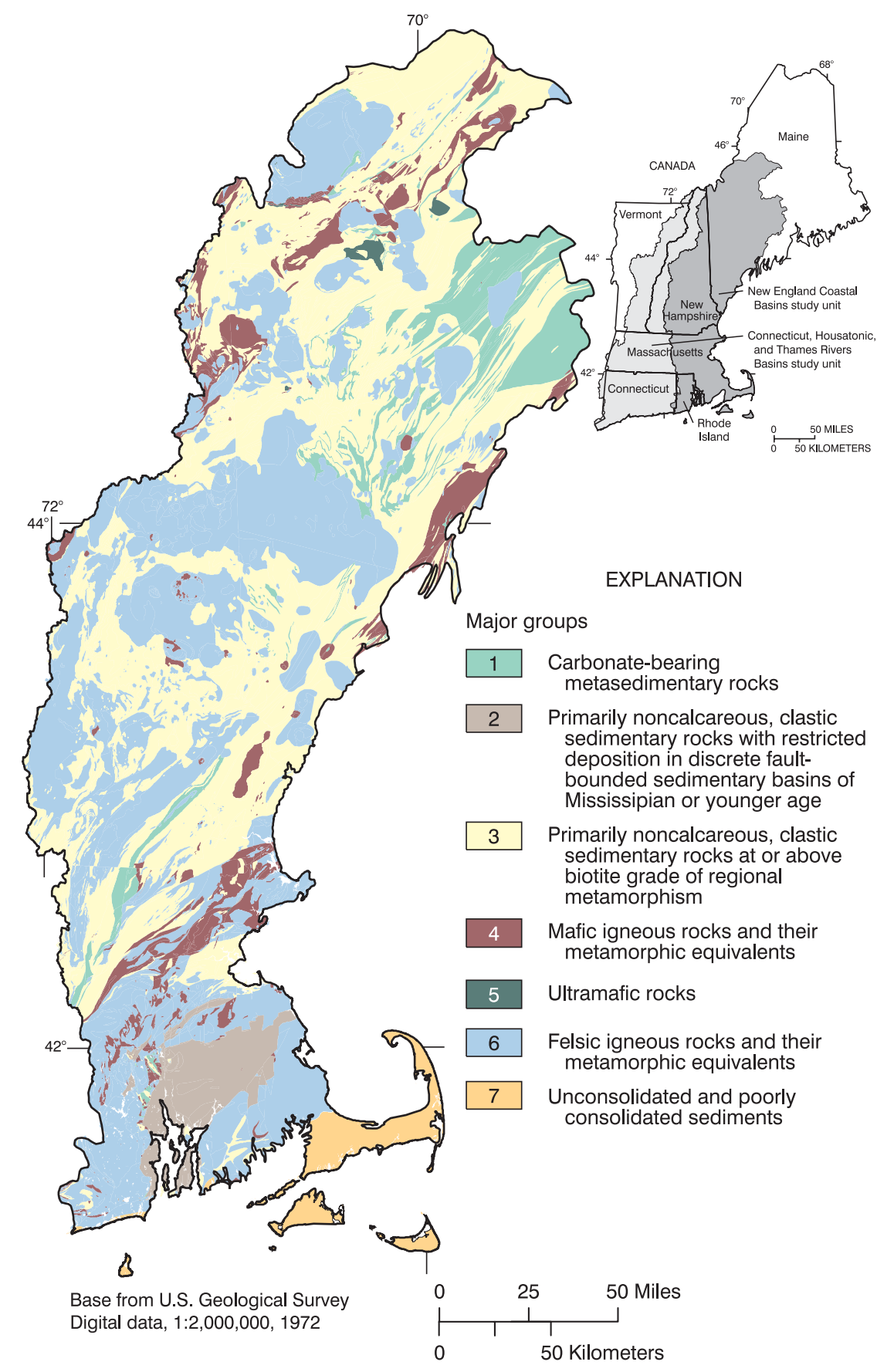

Figure 1. Areal distribution and description of the major groups of lithogeochemical units defined for the New England Coastal Basins study area. 
lithology and mineralogy for use in the interpretation of water-quality data. This Fact Sheet describes the geologic data sources that were compiled and the basis of the classification used in the digital data set. This Fact Sheet also describes the available formats of the digital data set and provides information on where to obtain these data on the World Wide Web.

The scheme for classifying bedrock units is based on geochemical principles, previous studies of the relations between water quality, ecosystem characteristics, and rock type, and the regional geology of New England. This classification scheme was first developed as part of the NAWQA study of the Connecticut, Housatonic, and Thames River Basins (CONN), an adjacent study area (fig. 1) (Robinson and others, 1999). Lithogeochemical characteristics of bedrock units were used by the NECB study to identify differences in the chemical quality of water from various bedrock aquifers (Ayotte and others, 1999) to determine strategies for monitoring ground-water quality in bedrock and surficial aquifers, and to characterize watersheds for surface-water and biological studies.

The chemical composition of surface water and ground water depends on a variety of climatic, geologic, geochemical, biochemical, anthropogenic, and hydrologic factors. Primary sources of most constituents in natural waters, however, are the minerals in sediments and rocks. Through the process of dissolution and weathering, minerals dissolve in water and alter its chemistry. Although the relation between these processes and other factors is complex, in similar climates, natural waters in contact with similar rock types often show similar chemical characteristics (Robinson, 1997). For the classification system used by the NECB study, more than 400 previously mapped bedrock units have been grouped into 38 lithogeochemical units, which are groups of bedrock units with similar mineral composition, texture and for some bedrock units, relative age. The lithogeochemical units have then been generalized into seven major groups (fig. 1), which are groups of lithogeochemical units that share similar geochemical and lithological features (fig. 2).

\section{Compilation of Geologic Data Sources}

The lithogeochemical data were derived and compiled from the five individual State geologic maps in the NECB study area (Osberg and others, 1985; Lyons and others, 1997; Zen and others, 1983; Hermes and others, 1994; and Rogers, 1985). Digital versions of the State geologic maps were stored in a geographic information system (GIS) so the bedrock units could be spatially grouped into lithogeochemical units and major groups. A lithogeochemical unit code, major group code, NAWQA-unit code, and State abbreviation were

Table 1. Descriptions of attributes in the lithogeochemical digital data set for the New England Coastal Basins study area

\begin{tabular}{|c|c|c|}
\hline Attribute & $\begin{array}{c}\text { Coverage } \\
\text { abbreviation }\end{array}$ & Description \\
\hline Bedrock & Bedrock & $\begin{array}{l}\text { This attribute identifies the predominant bedrock type in } \\
\text { the delineated areas, and is included to help identify } \\
\text { source materials for the line work and geologic } \\
\text { information. It is an alphabetic and numeric code. }\end{array}$ \\
\hline $\begin{array}{l}\text { Lithogeo- } \\
\text { chemical unit }\end{array}$ & Litho_unit & $\begin{array}{l}\text { This attribute represents the grouping of bedrock units that } \\
\text { are lithologically and geochemically similar. It is a } \\
\text { numeric and alphabetic code. }\end{array}$ \\
\hline Major group & Maj_group & $\begin{array}{l}\text { This attribute represents a classification of the } \\
\text { lithogeochemical units into broad groups. It is a single- } \\
\text { digit code. }\end{array}$ \\
\hline NAWQA unit & NAWQA-unit & $\begin{array}{l}\text { This attribute identifies New England Coastal Basins } \\
\text { study area as the National Water Quality Assessment } \\
\text { Program study unit associated with this digital data set. }\end{array}$ \\
\hline State & State & $\begin{array}{l}\text { This attribute identifies the State location of each polygon, } \\
\text { and is included to facilitate identification of source } \\
\text { materials for linework and geologic information. }\end{array}$ \\
\hline
\end{tabular}

assigned to each bedrock unit in the digital State geologic maps (table 1). The digital State geologic maps were joined in the NECB study area so the lithogeochemical digital data set could be created. A list of bedrock units from the individual State geologic maps that were classified into each lithogeochemical unit and each major group is provided in Robinson and others (2002, appendix A) and is available on the World Wide Web at http://water.usgs.gov/pubs/of/ ofr02-007.

Because each State bedrock geologic map was interpreted and assembled by different groups of geologists, the bedrock maps are not consistent from state to state. In particular, there are variations in the scales of the State bedrock maps, the descriptions of mineral assemblages in the formations, and the regional trends in lithology and metamorphic grade. These inconsistencies were minimized by classifying bedrock units into regional lithogeochemical units and major groups as shown in figure 1 .

\section{Classification Scheme}

This regional classification scheme groups bedrock units by major mineral and textural properties and by relative age for some bedrock units. This scheme is modified from the classification scheme described in Robinson and others (1999). The 38 lithogeochemical units defined for the NECB study area consider the combined effects of lithology, metamorphic grade, and geologic setting on water chemistry. Because some of these factors have more effect on water chemistry than others, some of the lithogeochemical units were subdivided into additional units with modifying attributes. For example, lithogeochemical units containing carbonate and sulfide minerals were subdivided because these highly reactive minerals have more effect on water chemistry than other minerals in the rocks of this region. Lithogeochemical units containing granitic units were subdivided to indicate relative age. This subdivision of granitic units represents a modification from the classification scheme described by Robinson and others (1999). A description of the lithogeochemical units and their potential effects on water quality can be found in Robinson and others (2002). 


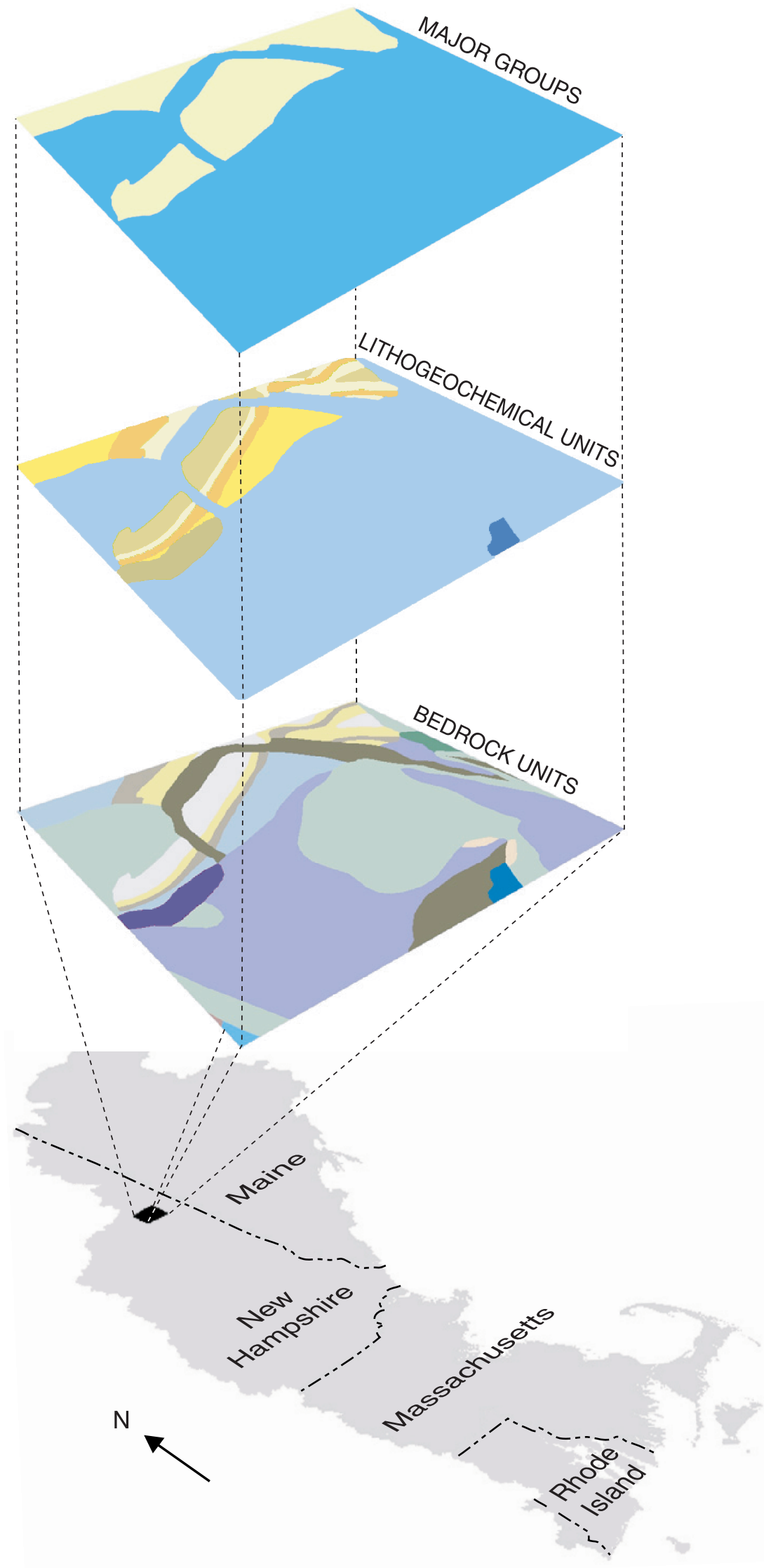

\section{EXPLANATION}

MAJOR GROUPS

Generalized groups of lithogeochemical units that share similar geochemical and lithological features

\section{LITHOGEOCHEMICAL UNITS}

Groups of bedrock units with similar mineral composition and texture, and, for some bedrock units, relative age

\section{BEDROCK UNITS}

Bedrock units, as defined by individual State geologic maps

Figure 2. Example application of the classification scheme that groups more than 400 bedrock map units defined in the New England Coastal Basin study area into 7 major groups (fig. 1) on the basis of similar lithology, mineralogy, and chemistry. 
The 38 lithogeochemical units are generalized into 7 major groups (fig. 1) that share similarities in overall geochemistry and lithology-(1) carbonate-bearing metasedimentary rocks; (2) primarily noncalcareous, clastic sedimentary rocks with restricted deposition in discrete fault-bounded sedimentary basins of Mississippian or younger age; (3) primarily noncalcareous, clastic sedimentary rocks at or above biotite-grade of regional metamorphism; (4) mafic igneous rocks and their metamorphic equivalents; (5) ultramafic rocks; (6) felsic igneous rocks and their metamorphic equivalents; and (7) unconsolidated and poorly consolidated sediments. Major group 7 includes areas in the southcoastal part of the NECB study area where the bedrock is overlain by thick glacial sediments at the surface. These surficial glacial deposits are the primary aquifers for these areas. An example of how bedrock units were classified or grouped into lithogeochemical units and then into major groups is shown in figure 2 for a small area of New Hampshire.

\section{Digital Products}

A digital data set that contains the major groups, lithogeochemical units, and bedrock units for the NECB study area is available on the World Wide Web at URL http://water.usgs.gov/pubs/of/ ofr02-007. These data can be retrieved as an ArcView shape file or an ARC/ INFO export file. The metadata (documentation) of the NECB lithogeochemical data set also is available with the digital data set. The metadata provides detailed information on data quality, spatial-data organization, spatial reference, spatial entities and attributes, and other aspects of the data set. Any use of trade, product, or firm names is for descriptive purposes only and does not imply endorsement by the U.S. Government.

\section{For more information on the NECB study and the NAWOA program, please contact:}

New England Coastal Basins

NAWQA study

U.S. Geological Survey

361 Commerce Way

Pembroke, NH 03275

(603) 226-7809

E-mail:

GS-W_NAWQA_NECB@usgs.gov Web Site: http://nh.water.usgs.gov

\section{Creating a New England Regional Lithogeochemical Digital Data Set}

The NECB and CONN study-unit lithogeochemical data sets can be combined to create a regional product (fig. 1). Both data sets were prepared following the same basic principles defined by Robinson (1997). When the two digital data sets are plotted side by side there are some notable discrepancies along the study unit boundaries between bedrock lines, lithogeochemical units, and major groups. These discrepancies are the result of modifications to the NECB data set (see the Classification Scheme section), differences in the digital-source materials for New Hampshire and Massachusetts, and differences in the bedrock units between the two study areas. The CONN data set (Robinson and others, 1999) can be obtained on the World Wide Web at http://water.usgs.gov/pubs/wri/wrig94000/.

Chief, NAWQA Program

U.S. Geological Survey

12201 Sunrise Valley Drive

National Center, MS 413

Reston, VA 20192

E-mail: nawqa_whq@usgs.gov

Web Site: http://water.usgs.gov/ nawqa/

\section{References Cited}

Ayotte, J.P., Nielsen, M.G.,

Robinson, G.R., Jr., and

Moore, R.B., 1999, Relation of arsenic, iron, and manganese in ground water to aquifer type, bedrock lithogeochemistry, and land use in the New England Coastal Basins:

U.S. Geological Survey Water-

Resources Investigations Report 99-4162, $61 \mathrm{p}$.

Hermes, O.D., Gromet, L.P., and Murray, D.P., 1994, Bedrock geologic map of Rhode Island: Kingston, R.I., Office of the Rhode Island State Geologist, Rhode Island Map Series no. 1, 1 map sheet, 1:100,000.

Flanagan, S.M., Nielsen, M.G., Robinson, K.W., and Coles, J.F., 1999, Water-quality assessment of the New England Coastal Basins in Maine, Massachusetts, New Hampshire, and Rhode Island: Environmental settings and implications for water quality and aquatic biota: U.S. Geological Survey WaterResources Investigations Report 98-4249, 62 p.

Lyons, J.B., Bothner, W.A., Moench, R.H., and Thompson, J.B., Jr., 1997, Bedrock geologic map of New Hampshire: U.S. Geological Survey Special Map, 2 map sheets, $1: 250,000$.

Osberg, P.H., Hussey, A.M. II, and Boone, G.M., 1985, Bedrock geologic map of Maine: Augusta,
Maine, Maine Geological Survey, 1 map sheet, 1:500,000.

Robinson, G.R., Jr., 1997, Portraying chemical properties of bedrock for water quality and ecosystem analysis: An approach for the New England Region: U.S. Geological Survey Open-File Report 97-154, $17 \mathrm{p}$.

Robinson, G.R., Jr., Ayotte, J.P., Montgomery, D.L., and DeSimone, L.A., 2002, Lithogeochemical character of near-surface bedrock in the New England Coastal Basins: U.S. Geological Survey Open-File Report 02-007 (digital), accessed December 2001, at URL http://water.usgs.gov/lookup/ getspatial?ofr02-007_lithogeo.

Robinson, G.R., Jr., Peper, J.D., Steeves, P.A., and DeSimone, L.A., 1999, Lithogeochemical character of near-surface bedrock in the Connecticut, Housatonic, and Thames River Basins: U.S. Geological Survey Water-Resources Investigations Report 99-4000 (digital), accessed April 26, 2001, at URL http:// water.usgs.gov/lookup/ getspatial?wri99-4000_lithogeo.

Rogers, John (compiler), 1985, Bedrock geological map of Connecticut: Connecticut Geologic and Natural History Survey, 2 map sheets, 1:125,000.

Zen, E-an, Goldsmith, G.R., Ratcliffe, N.L., Robinson, Peter, and Stanley, R.S., 1983, Bedrock geologic map of Massachusetts: U.S. Geological Survey, Monograph series, 3 map sheets, 1:250,000.

-By Denise L. Montgomery, Gilpin R. Robinson, Jr., Joseph D. Ayotte, Sarah M. Flanagan, and Keith W. Robinson 